\title{
The Effect of Differences Leachate Concentration and Material Properties on Electrical Conductivity of Volcanic Deposits - Case Studies Piyungan Landfill Bantul Yogyakarta
}

\author{
Jaingot A. Parhusip ${ }^{* 1,2}$, Agung Harijoko ${ }^{1}$, Doni Prakasa Eka Putra ${ }^{1}$, and Wiwit Suryanto ${ }^{3}$ \\ ${ }^{1}$ Department of Geological Engineering, Faculty of Engineering, Gadjah Mada University, Yogyakarta, Indonesia \\ ${ }^{2}$ Department of Mining Engineering, Faculty of Engineering, Cendrawasih University, Indonesia \\ ${ }^{3}$ Department of Geophysics, Faculty of Mathematics and Natural Sciences, Gadjah Mada University, Indonesia
}

\begin{abstract}
Monitoring at the contaminated subsurface soil, have been conducted by using the geophysical surface method, especially for geoelectrical resistivity method. Monitoring is commonly conducted by using geoelectrical resistivity through measuring the value of Electrical Resistivity (ER) or Electrical Conductivity (EC) of leachate contaminated soil layer. EC measurement value of soil is affected by many factors, among others, particle conduction of soil materials, surface conduction, fluid conduction in the pores as well as the effect of particle shape and soil materials. Piyungan landfill is the main disposal site of Yogyakarta municipal solid waste. This landfill located mainly on the tertiary rocks of volcanic rocks and its weathering products. In order to improve the accuracy of geoelectrical measurements on resistivity in monitoring soil layers from contaminated leachate on this area, this research conducted several measurements on physical properties of soil sample and electrical properties of leachate in the saturated soil samples. The measurement of physical properties includes: porosity, clay content, particle content, and cation exchange capacity (CEC) value. The soil samples were collected from 3 locations around Piyungan Landfill. Type of soils are taken from the alluvial deposits (Sample B), weathered tuffaceous sandstone-claystone (Sample D), and weathered andesitic breccia (Sample F). Samples were made in containers, saturated with aquades-leachate solution with 12 different concentration levels. Electrical conductivity (EC) was measured by using Soil Box Miller and Geoelectric Resistivity Oyo McOhm. According to results of physical properties analysis, the grain size of soils are dominantly sandy clayey silt in grain size distribution, with clay content ranging from 33.0--38.4\%, the CEC values ranging from 26.8--52.7 meq/100 gr, and the porosity of samples B, D and F is $58.85 \%, 55.30 \%, 59.24 \%$, respectively. Based on the experiments with 12 different leachate concentrations, there is a linear increase in EC of $0.718 \mu \mathrm{S} / \mathrm{cm}$ for every increase in electrical conductivity pore fluid $\left(\mathrm{EC}_{f}\right) 1 \mathrm{mg} / 1$ in samples B, while in samples D and $\mathrm{F}$ are $0.492 \mu \mathrm{S} / \mathrm{cm}$ and $0.284 \mu \mathrm{S} / \mathrm{cm}$ respectively. Plotting the data of $\mathrm{EC}$ vs $\mathrm{EC}_{f}$ for each samples and $\mathrm{ER}$ vs $\mathrm{EC}_{f}$, it can be concluded the slope of $\Delta \mathrm{EC} / \Delta \mathrm{EC}_{f}$ differ for each samples and the electrical conductivity value of different concentration of leachate is very sensitive for alluvial deposits compare to the weathered tuffaceous sandstone-claystone and weathered volcanic breccia deposits.
\end{abstract}

Keywords: Electrical conductivity · Cation exchange capacity $\cdot$ Leachate $\cdot$ Soil · Volcanic deposits.

\footnotetext{
${ }^{*}$ Corresponding author: J.A. PARHUSIP, Department of Geological Engineering, Faculty of Engineering, Gadjah Mada University. Jl. Grafika 2 Yogyakarta, Indonesia. Email: jaingotparhusip@yahoo.com
}

\section{INTRODUCTION}

Landfill is the most often used method for dumping disposal site in urban areas. How- 
ever, the landfill often becomes a potential source of groundwater contamination because containing high concentration of chemical elements (Mac Farlane et al., 1983; Rapti-Caputo et al., 2006; Reyes-López et al., 2008) . Therefore, in the landfill dumping site it is necessary to monitor the probability of leachate seepagein the soil and groundwater continuously in the surrounding area of the landfill.

Many soil and groundwater quality monitoring at the contaminated subsurface soil, have been conducted by using the geophysical surface method, especially for geoelectrical resistivity method. Monitoring is conducted by using geoelectrical resistivity through measuring the value of Electrical Resistivity (ER) or Electrical Conductivity (EC) of leachate contaminated soil layer (Abbaspour et al., 2000; Meju, 2000; Porsani et al., 2004). EC measurement value of soil is affected by many factors, among others, particle conduction of soil materials, surface conduction, fluid conduction in the pores as well as the effect of particle shape and soil materials. Electrical Conductivity of fluid $\left(\mathrm{EC}_{f}\right)$ is the dominant factor in measuring the $\mathrm{EC}$ value of soil, which is influenced by the chemical concentration and composition of pore fluid (McCarter, 1983; Kalinski and Kelly, 1994; Klein and Santamarina, 2003).

The purpose of this research to find the electrical characteristics of volcanic deposits saturated leachate as Piyungan landfill overlying such kind of lithology.Research conducted by Longo (2014) obtained ER value of volcanic deposits are between 4-20 Ohm-m (Longo et al., 2014). On this research, samples were obtained from the volcanic deposits around Piyungan landfill. This layer consists of alluvial deposits, weathered andesitic breccia and weathered sandstone-tuffaceous claystone $(\mathrm{Pu}-$ tra, 2001). Data of ER or EC values of soil layering and pore fluid filler is required as a binder to improve the accuracy of data interpretation of the soils layering lithology on the geoelectric resistivity measurements (Meju, 2000).

\section{STUdy AREA}

The areas of Piyungan Landfill and surrounding are covered by Quarternary and Tertiary rocks, which are the Young Merapivolcanicdeposits, Alluvial Deposits and the lower-middle

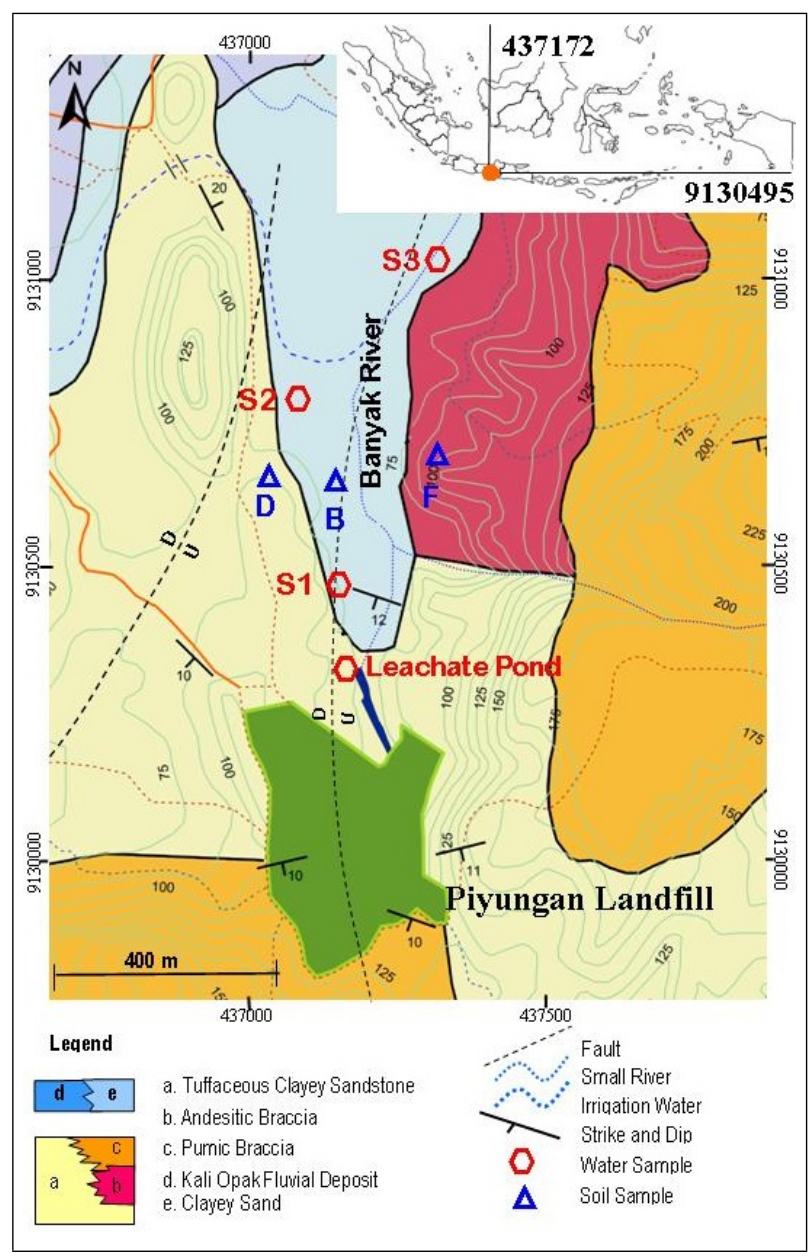

Figure 1: Geological map (Putra, 2001) and soil sampling locations (B1, B2, B3, B4, D and F), leachate pond sample location, and groundwater sample location from the dug well S1, S2 and S3.

Miocene rocks called as Semilir Formation (Raharjo et al., 1995).

The lithology contained in the study area can be divided into five lithological units, namely; sandstone-tuffaceousclaystone unit, andesitic breccia units, breccia pumice unit pumice which is a product of the tertiary rocks, and Opak River's alluvial and fluvial deposition units and which is a quarternary deposit product (Putra, 2001). Banyak River is a disposal river for leachate from the Piyungan landfill, flowing across the alluvial deposits from the South to North (Figure1).

\section{THEORETICAL BACKGROUND}

The Waxman and Smits Equation (Waxman and Smith, 1968; Sen et al., 1998) explains the correlation between the EC of soil fluid (electrolyte) 
with the electrical conductivity of clay material. EC material is represented by the Cation Exchange Capacity (CEC) value of the clay:

$$
\mathrm{EC}=\frac{1}{F}\left(\mathrm{EC}_{f}+B Q_{v}\right)
$$

where $F$ is related to the porosity $\phi$ with Arcie equation of $1 / F=\phi^{m}$ in which $m$ is the porosity exponent of Archie equation with a value of $m \approx 2$ and $B$ is the equivalent counter ion mobilityof clay surface.

$$
B=B_{0}\left[1-0.6 \exp \left(-\frac{\mathrm{EC}_{f}}{0.013}\right)\right]
$$

where $E C_{f}$ is the electrolyte conductivity in S.m ${ }^{-1}$ and the maximum counterion equivalent mobility is given by the value of $B_{0}=$ $4.78 \times 10^{-8} \mathrm{~m}^{2} \mathrm{~s}^{-1} \mathrm{~V}^{-1}$. Meanwhile, the $Q_{v}$ value shows the CEC with an equation:

$$
Q_{v}=\rho_{\text {mat }} \frac{(1-\phi)}{\phi} \mathrm{CEC}
$$

where $\rho_{\text {mat }}$ is the matrix density in $\mathrm{kg} . \mathrm{m}^{-3}$.

The CEC values for some clay minerals are available in Table 1, ranging from 3-150 (meq/100gram) from Eslinger and Pevear (Ismadji at al., 2015).

Table 1: The CEC values for some clay minerals. The CEC values of clay ranging from 3--130 $\mathrm{meq} / 100 \mathrm{~g}$, from Eslinger and Pevear (Ismadji et al., 2015)

\begin{tabular}{lc}
\hline Clay mineral & CEC, meq/100 g \\
\hline Allophane & 70 \\
Kaolinite & $3-15$ \\
Halloysite & $5-10$ \\
Sodium Montmorillonite & $80-130$ \\
Calcium Montmorillonite & $40-70$ \\
Hectorite & $80-130$ \\
Palygorskite & $30-40$ \\
Sepiolite & $30-40$ \\
Illite & $10-40$ \\
Vermiculite & $100-150$ \\
\hline
\end{tabular}

\section{Materials ANd Methods}

\section{Materials}

Soil samples were collected from 6 locations around the Piyungan landfill, Yogjakarta (See Figure 1). Sampling were taken at a depth of
40-50 cm, except for the samples in location B that were taken from four different locations and depths. Point B1, B2, B3 and B4 are derived from a single point location with a depth of $1.0 \mathrm{~m}, 1.5 \mathrm{~m}, 2.5 \mathrm{~m}$ and $3.0 \mathrm{~m}$, respectivley. Point B1, B2, B3, and B4 are in alluvial deposit. Point $D$ is located at the location of the tuffaceous sandstone-claystone deposit, while point F is located at andesitic breccia unit. Each samples were made into two parts for the measurements of physical and electrical properties of the sample. Groundwater samples were collected from dug well S1, S2 and S3. Leachate sample was collected from the leachate pond.

\section{Measurements of physical and electrical prop- erties of the samples}

a. Measurements on the physical properties of the soil; density, porosity, grain size distribution and the value of the CEC, conduct with the pycnometer, hydrometry and percolate distillation methods. The tests were conducted in the laboratory of Institute for Agricultural Technology (BPTP) of Yogyakarta.

b. The measurement on the resistivity value of the sample was conducted in the laboratory of Environmental Geological Engineering of Gadjah Mada University of Yogyakarta. Each sample was dried for $3 \times 24$ hours. Each type of samples was then put into the 12 different sample containers with the same weight. Each sample was saturated with the aquades-leachate solution with 12 different levels concentration. The leachate was obtained from the leachate pond of Piyungan landfill. 11 samples used an aquades-leachate solution ranging from $10 \mathrm{mg} / 1$ to $350 \mathrm{mg} / 1$ and 1 sample used ground water. The samples were stirred evenly until the soil samples were saturated based on the standard (ASTM-G57a, 1995). There were 72 containers of saturated samples were then left for 24 hours to ensure saturation of samples. The saturated samples were then put into the soil box Miller (sketch in Figure 2), compacted evenly, and then measured for its EC values (Kowalzczyk et al., 2014).

c. Electrical Resistivity (ER) values measurements used a Geoelectric Resistivity Oyo 


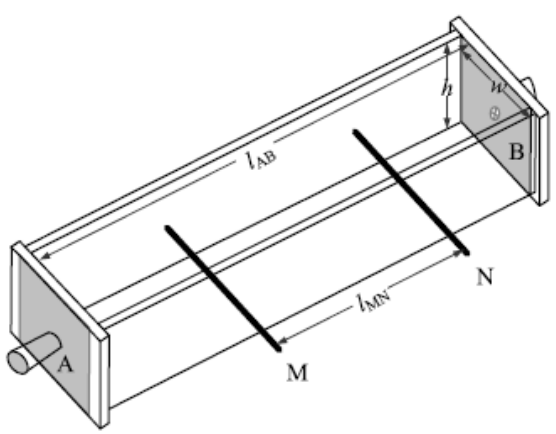

Figure 2: Soil box Millers scheme, A and B are the electrodes of electric current, $\mathrm{M}$ and $\mathrm{N}$ are the electrodes of electric potential. Electrodes $\mathrm{A}$ and $\mathrm{B}$ are made of stainless-steel fragments, with a thickness of $1 \mathrm{~mm}$, and distance of $22 \mathrm{~cm}$. Electrodes $\mathrm{M}$ and $\mathrm{N}$ that are made of $4 \mathrm{~mm}$ diameter copper nails, with a length of $5 \mathrm{~cm}$, are made in a distant of $12 \mathrm{~cm}$ (ASTM-G57a, 1995).

$\mathrm{McOhm}$. By using four electrodes method, 2 current electrodes and 2 potential electrodes, the current is conducted through the electrodes A and B that are made of stainless-steel fragments with a thickness of $1 \mathrm{~mm}$, and a distance of $22 \mathrm{~cm}$. M and $\mathrm{N}$ electrodes that are made of $4 \mathrm{~mm}$-diameter copper nails, with a length of $5 \mathrm{~cm}$, are made in a distance of $12 \mathrm{~cm}$. The data of sample resistivity were analyzed through graphics of the relationship of the effect of the level of EC change due to the increase of TDS concentration level of the pore fluid filler.

\section{Results ANd Discussion}

\section{Physical properties}

Physical properties of the sampless how on Table 2. According to the percentage value of the grain size, sample B, D and F are classified as sandy clayey silt. All samples had a total porosity of greater than $55 \%$. Weathered andesitic brecciashas a porosity of $59.24 \%$, alluvial deposits $58.85 \%$ and weathered tuffaceous sandstone-claystone $55.30 \%$, respectively. Alluvial deposit samples contain higher clay percentage compare toweathered andesitic breccia and weathered tuffaceous clay sandstone.

However, the clay contain seem to be not linear to the CEC value (see Figure 3). The CEC values are ranging from $26.8-52.7 \mathrm{meq} / 100 \mathrm{gr}$.
Table 2: The physical parameter of lithology around Piyungan landfill (CEC in meq/100gr).

\begin{tabular}{ccccccc}
\hline $\begin{array}{c}\text { Soil } \\
\text { Sam- } \\
\text { ple }\end{array}$ & $\rho$ & $\begin{array}{c}\phi \\
\text { Total } \\
(\%)\end{array}$ & $\begin{array}{c}\text { Sand } \\
>50 \mu \\
(\%)\end{array}$ & $\begin{array}{c}\text { Silt } \\
2-50 \mu \\
(\%)\end{array}$ & $\begin{array}{c}\text { Clay } \\
<2 \mu\end{array}$ & CEC \\
$(\%)$ & \\
\hline B & 2.48 & 55.30 & 14.50 & 46.70 & 38.80 & 32.94 \\
D & 2.53 & 58.85 & 18.67 & 44.67 & 36.67 & 26.60 \\
F & 2.48 & 59.24 & 26.67 & 40.33 & 33.00 & 36.40 \\
\hline
\end{tabular}

B: Alluvial deposit

CD: Weathered tuffaceous sandstone-claystone

F: Weathered andesitic breccias

\section{Average value for sample B, D, F}

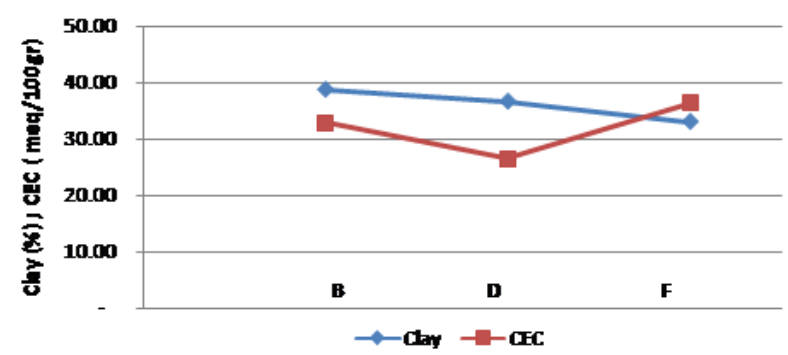

Figure 3: The graphic of average clay content percentages and CEC values of volcanic deposits around Piyungan landfill. The CEC values are in meq/100g and clay content in \%.

The highest CEC value measured on sample $\mathrm{F}$ of weathered andesitic breccia, and the lowest CEC measured from sample D of weathered tuffaceous sandstone-claystone.

\section{Electrical conductivity measurements}

The electrical conductivity values of samples with different combination of leachate concentration is show in Table 3. The groundwater samples used in the measurements was from a dug well located approximately $650 \mathrm{~m}$ downstream from waste processing disposal of Piyungan landfill. The dug well has been classify as contaminated by leachate from Piyungan landfill (Phonhalath, 2012). The $\mathrm{EC}_{f}$ value of this ground water is equal to the $\mathrm{EC}_{f}$ value of aquades-leachate fluid that is $410 \mu \mathrm{S} / \mathrm{cm}$ at the same TDS concentration of $200 \mathrm{mg} / \mathrm{L}$. However, the EC of the ground water-saturated soil sample has a lower value than the aquades-leachate saturated sample. It is probably due to effect of different types of ions in the ground water containing ions in the 
aquades-leachate fluid that result in different EC values (Parhusip, et al., 2016).

From the measurements, it can be obtained that the leachate-aquades solution with TDS values ranging from $10 \mathrm{mg} / 1$ to $350 \mathrm{mg} / 1$ has an EC value ranging about $30 \mu \mathrm{S} / \mathrm{cm}$ to $710 \mu \mathrm{S} / \mathrm{cm}$. There is an increase in EC linearly with the average increase of $0,82 \mu \mathrm{S} / \mathrm{cm}$ for every additional leachate TDS of $1 \mathrm{mg} / 1$ (Table 3). Concentration of TDS from $10 \mathrm{mg} / 1$ to $350 \mathrm{mg} / 1$ wi have EC of samples D and F are about $347 \mu \mathrm{S} / \mathrm{cm}$ to $796 \mu \mathrm{S} / \mathrm{cm}$ than samples B around $1027 \mathrm{uS} / \mathrm{cm}-1473 \mathrm{uS} / \mathrm{cm}$. From Table 3. the value of ER can be calculated as ER is reciprocal value of EC. ER sample D, F and B are 19.3-28.8 Wm, 12.6-22.9 Wm 6.8-9.7 Wm, respectively. And if sample saturated with ground water ER for D, F and B are $17.2 \mathrm{Wm}$, $24 \mathrm{Wm}$, and $7.5 \mathrm{Wm}$, respectively. All of the samples that were saturated by fluid aquadesleachate or by groundwater have increases in EC linearly due to the increase of $\mathrm{EC}_{f}$ (Figure 4 and Table 4 .

Table 3: The electrical conductivity values of samples B,D and F, after being saturated by aquades-leachatefluids with 12 different levels of TDS concentration.

\begin{tabular}{ccccc}
\hline \multicolumn{2}{c}{$\begin{array}{c}\text { Fluid } \\
\text { (Aquades+leachate) }\end{array}$} & \multicolumn{3}{c}{$\begin{array}{c}\text { Electrical Conductivity Sample } \\
\text { (Aquades+leachate+soil) }\end{array}$} \\
$\begin{array}{c}\text { TDS } \\
\mathrm{mg} / \mathrm{L}\end{array}$ & $\mathrm{EC}_{\text {mud }}$ & \multicolumn{1}{c}{$\mathrm{B}$} & $\mathrm{D}$ & $\mathrm{F}$ \\
\hline 10 & 30 & 1105 & 437 & 347 \\
20 & 70 & 1027 & 520 & 370 \\
50 & 110 & 1088 & 486 & 358 \\
70 & 160 & 1043 & 575 & 377 \\
100 & 210 & 1100 & 551 & 424 \\
150 & 310 & 1312 & 593 & 436 \\
200 & 410 & 1360 & 687 & 447 \\
220 & 450 & 1462 & 667 & 466 \\
250 & 500 & 1376 & 718 & 509 \\
300 & 610 & 1405 & 769 & 549 \\
350 & 710 & 1473 & 796 & 517 \\
$200^{*}$ & 410 & 1333 & 582 & 416 \\
\hline
\end{tabular}

*) groundwater

In Equation 1, it shows that EC is a function of the EC value of the electrolytes in the pores, where the density, porosity and CEC values of the samples are the constant magnitude as seen in Figure 4a. The graphic of the change of resistivity values of the sample towards the increase in $\mathrm{EC}_{f}$ (Figure $4 \mathrm{p}$ ) shows that the slope of the
Table 4: The equation of the graphs of EC value change versus the increase of $\mathrm{EC}_{f}$ value and

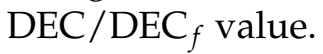

\begin{tabular}{|c|c|c|c|}
\hline Sample & $Y$ & $R^{2}$ & 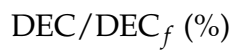 \\
\hline B & $0.718 X+1018$ & 0.852 & 71.8 \\
\hline $\mathrm{D}$ & $0.492 X+4519$ & 0.917 & 49.2 \\
\hline $\mathrm{F}$ & $0.284 X+3405$ & 0.889 & 28.4 \\
\hline
\end{tabular}

graphic of samples D and $\mathrm{F}$ is higher than of samples B. The slope of the graphic B is also greater than the graphic $D$ and $F$. It is mean that the measurements of EC in the contaminated soil layers $B$, are more sensitive compare to the soil layers of $\mathrm{D}$ and $\mathrm{F}$.

Comparing the physical properties of soils and results of the experiments (See Table 2 and Figure 4). It can be seen that the value of EC or ER have linear relationship with the clay content but not with CEC. The relationship is the highest the clay content, the highest the EC value, but for ER value, the highest the clay content, the lowest the ER value. This fact shows how important the existing of clay content on the value of EC and or ER measurement.

\section{CONCLUSION}

Based on the experiments, it reveals that the change of EC value of the contaminated soil is more sensitive on the soil of alluvial depositsthan soil from weathered tuffaceous sandstone-claystone and from weathered andesitic breccia. It means that the increased conductivity of soil saturated leachate, will be higher in the alluvial depositscompared with the weathered tuffaceous clay sandstone and weathered andesitic breccia.

This condition will affect the electric resistivity value of soils during the geoelectrical survey in the field. Different value of resistivity will be measured on the field of leachate contaminated area on different type of soils/rocks. Therefore, the data and results on this research can be used in the field as references to predict the contamination the leachate-saturated soil layer in the study area.

\section{ACKNOWLEDGEMENTS}

The authors would like to thanks the Directorate General of Higher Education, Ministry of Research and Higher Education of Indone- 


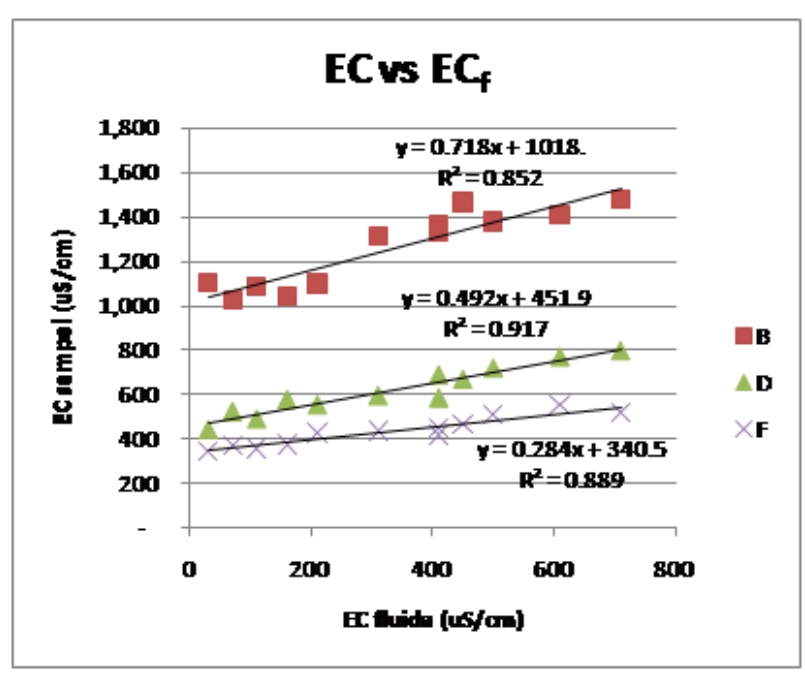

(a)

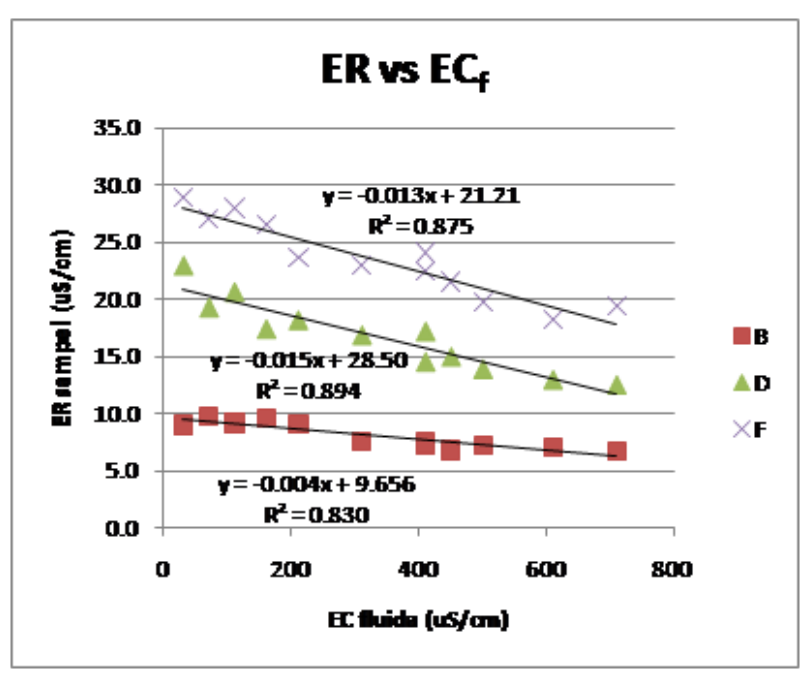

(b)

Figure 4: (a).The graphic of the change in EC values towards the increase of ECf.values. (b). The graphics of the change in ER values towards the increase in ECfvalue.

sian Goverment who has funded this research by Postgraduate Education Scholarship. Our sincere thanks to the management of Piyungan Landfil, which has given us permission to do this research in the Piyungan landfill area. We also would like to give appreciation to the Head and staff of Department of Geological Engineering, Gadjah Mada University, who gave the permission to access equipment and laboratories. Last but not least, special thanks to $\mathrm{Mr}$. Joko Riyanto for support during the laboratory works.

\section{REFERENCES}

Abbaspour, K., Matta V., Huggenberg, P., Johbson, C.A. (2000) A contaminated site investigation: comparison of information gained from geophysical measurements and hydrogeological modeling. Journal of Contaminant Hydrology 40: 365380.

ASTM-G57a (1995) Standard method for field measurement of soil resistivity using the Wenner fourelectrode method.ASTM Designation: G57-95a: 211-215.

Ismadji, S., Soetaredjo, F.E., Citra, A.A. (2015) Clay materials for Environmental Remediation. Springer Briefs in Molecular Science, ISSN 21915415 (electronic).

Kalinski, R.J. and Kelly, W.E. (1994) Electricalresistivity measurements for evaluating compacted-soil liners. Journal of Geotechnical Engineering 120: 451-457.

Klein, K.A. and Santamarina, J.C. (2003) Electrical Conductivity in soil. Journal of Environmental and Engineering Geophysics 8: 15-22

Kowalczyk, S.., Maslakowski, M., and Tucholka, P.
(2014) Determination of the correlation between the electrical resistivity of non-cohesive soils and the degree of compaction. Journal of Applied Geophysics 110: 43-50.

Longo. V., Testone, V., Oggiano, V. and Testa, A. (2014) Prospecting for clayminerals within volcanic successions: Application of electrical resistivity tomography to characterise bentonite deposits in northern Sardinia (Italy). Journal of Applied Geophysics 111: 21-32.

Mac Farlane, D.S., Cherry, J.A., Gillham R.W., Sudicky, E.A. (1983) Migration of contaminants in groundwater at a landfill: a case study. In: Cherry, J.A. (Ed.), Groundwater Flow and Plume Delineation. J. Hydrology. Special Issue 63:1-29.

McCarter, W. (1984) The electrical resistivity characteristics of compacted clays. Geotechnique 34: 263-267. http://dx.doi.org/10.1016/ j.wasman.2008.03.024. Accesesed, 14 March 2016.

Meju, M.A. (2000) Geoelectrical investigation of old/abandoned, covered landfill sites in urban areas: model development with a genetic diagnosis approach. Journal of Applied Geophysics 44: 115150

Parhusip, J.A., Harijoko, A., Putra, D.P.E., Suryanto, W. (2016) Electrical Conductivity of Ions Major and Heavy Metal Contribution for Electrolyte Electrical Conductivity of Leachate and Groundwater in Piyungan Landfill, Bantul Yogyakarta. Proceeding of Annual Basic Science International Conference Vol. 6: 201-205.

Phonhalath, K. (2012) Hydrogeological Control on Fate Processes of Heavy Metal and Organic Chemical Contaminants from Landfill, case study: Piyungan Landfill, Yogyakarta Special Province, Indonesia. Dissertation, Faculty Engineering Gadjah Mada University, pp.306. 
Porsani, J.L., Filho, W.M., Elis, V.R., Shimeles F., Dourado J.C. (2004) The use of GPR and VES in delineating a contamination plume in a landfill site: a case study in SE Brazil. Journal of Applied Geophysics 55: 199-209.

Putra, D.P.E. (2001) Pencemaran Leachate Pada Air tanah di Area Tempat Pembuangan Akhir Sampah Piyungan dan Sekitarnya Kecamatan Piyungan Kabupaten Bantul Yogyakarta. Program Studi Teknik Geologi, Jurusan Ilmu ilmu Teknik-Program Pascasarjana UGM, Yogyakarta. Pp. 180.

Rahardjo, W., Sukandarrumidi, Rosidi (1995) Peta Geologi Lembar Yogyakarta, Jawa. Direktorat Geologi Deptamben RI, Bandung.
Rapti-Caputo D., Vaccaro C. (2006) Geochemical evidences of landfill leachate in groundwater. Engineering Geology 85: 111-121.

Reyes-López, J.A., Ramírez-Hernández, J., LázaroMancilla, O., Carreón-Diazconti, C., Garrido, M.M.L. (2008) Assessment of groundwater contamination by landfill leachate: a case in México. Waste Management.

Waxman, M.H. and Smits, L.J.M. (1968) Electrical conductivities in oil bearing shally sands. Society of Petroleum Engineers Journal 8: 107-122.

Sen, P.N., Goode, P.A., Sibbit , A. (1988) Electrical Conduction in Clay Bearing Sand-Stones at low and High Salinities. Journal of Applied Physics 63: 4832-4840. 